\section{Endocrine profiles and ovulation rate of cow superovulated with FSH following passive immunization against steroid free-bovine follicular fluid*}

\author{
Perfis endócrinos e taxa de ovulação de vacas \\ superovuladas com FSH após imunização passiva \\ contra líquido folicular bovino livre de esteróides
}

\author{
CORRESPONDENCE TO: \\ Rafael Herrera Alvarez \\ Seção de Reprodução e Inseminação \\ Artificial \\ Instituto de Zootecnia \\ Caixa Postal 60 \\ 13460-000 - Nova Odessa - SP \\ e-mail: herrera@izsp.br \\ 1 - Seção de Reprodução e Inseminação Ar- \\ tificial do Instituto de Zootecnia - SP \\ 2 - Departamento de Fisiologia da Faculda- \\ de de Medicina da USP - SP \\ 3 - Departamento de Bioengenharia do Insti- \\ tuto de Pesquisas Energéticas e Nucleares - SP \\ 4 - Departamento de Reprodução Animal da \\ Faculdade de Ciências Agrárias e Veteriná- \\ rias da UNESP - SP
}

\author{
Rafael Herrera ALVAREZ1'; João Batista Pereira de CARVALHO'; Alzira ROSA E SILVA²; \\ Cibele Nunes PERONE${ }^{3}$; Maria Tereza Carvalho Pinto RIBELA ${ }^{3}$; Enoch Borges de OLIVEIRA FILHO ${ }^{4}$
}

\begin{abstract}
SUMMARY
Ten multiparous non-lactating cows were randomly assigned to one of two groups. On days 8 to 12 after estrus, the first group was given $100 \mathrm{ml}$ antiserum against steroid-free bovine follicular fluid (anti-bFF), which was produced in ovariectomized sheep. The second group (control) was given $100 \mathrm{ml}$ nonimmune ovariectomized sheep serum. Six hours after injection, both groups were superovulated with FSH (18 NIH-FSH-S1 units) and LH (0.29 NIH-LH-S1 units) in a 4-day decreasing regime. On the morning of the third day a luteolytic dose of prostaglandin $\mathrm{F}_{2}$ a analogue (cloprostenol) was given. Artificial inseminations (AI) were done 48 and $60 \mathrm{~h}$ later. Embryos were collected 7 days after AI by a nonsurgical method. Blood samples were taken throughout the experimental period and plasma concentrations of FSH, LH and progesterone were determined by radioimmunoassay. All cows from the immunized group, and 3 out of 5 cows in the control group, had more than 2 CL. There was no significant difference $(p>0.05)$ in the ovulation rate between immunized and control groups (14.4 and 9.9, respectively). The number of recovered embryos was not significantly different $(\mathrm{p}>0.05)$ between groups, although cows immunized against bFF had a greater number of transferable embryos $(3.4 \pm 1.0$ versus $0.8 \pm 0.4, \mathrm{p}<0.05)$. Plasma gonadotrophin concentrations were not correlated with either ovulation rate or number of recovered embryos. Plasma progesterone concentration was positively correlated $(r=0.88, p<0.01)$ to ovulation rate. Results suggested that passive immunization of cows with anti-bFF before superovulation did not reduce the variability of ovarian response.
\end{abstract}

UNITERMS: Superovulation; Follicular fluid; Passive immunization; Embryos; Cattle.

\section{INTRODUCTION}

I n spite of the considerable progress in embryo splitting and in vitro fertilization techniques, superovulation with gonadotrophins is still the most feasible and widely used process for both research and applied embryo transfer programs in cattle $^{13}$. The major disadvantage of gonadotrophin treatment is the great variability of ovarian response between and within animals $\mathrm{s}^{3,5,12}$. For instance, data analysis from 960 cows treated for superovulation during a 10-year period (in the Embryo Transfer Unit of the Instituto de Zootecnia, Nova Odessa, SP, Brazil) showed an average of 6.1 recovered embryos but the standard deviation was 5.1.

The two most important factors affecting variability in ovarian response are: a) gonadotrophin treatment per $\mathrm{se}^{3,19}$ and b) ovarian status at the time of gonadotrophin treatment ${ }^{17,18}$.

There have been many attempts to improve the superovulatory response. Using different gonadotrophin preparations or increasing the number of follicles available for stimulation by pretreatment with $\mathrm{FSH}^{27}$ or $\mathrm{GH}^{11}$ have been somewhat successful in increasing the ovulation rate and the number of transferable embryos. However, these methods did not reduce the variability of ovarian response. Initiating superovulation in the absence of a functionally dominant follicle is an efficient way of increasing the number of recovered embryos and reducing the variability. The disadvantage of such a method is that it requires either an ultrasonic monitoring ${ }^{7}$ or a surgical electrocautery ${ }^{15}$.

The dominance of growing follicles can be suppressed using immunological techniques as shown in non-superovulated cattle passively immunized against inhibin ${ }^{25}$ or charcoal-treated bovine follicular fluid ${ }^{1}$. The use of inhibin for immunization is somewhat limited by cost and availability. In contrast, bovine follicular fluid can be readily aspirated from abattoir-derived ovaries. In the studies above, the ovulation rate was moderately increased by immunization. Therefore, it is possible that such a method can also contribute to render the animals more sensitive to exogenous gonadotrophins.

* Abstract presented in the International Embryo Transfer Society 1977 Anual Meeting, Nice, France. 
The objective of the present study was to determine the endocrine and superovulatory responses of FSH-treated cows passively immunized against charcoal-treated bovine follicular fluid.

\section{MATERIAL AND METHOD}

\section{Antiserum bFF}

Antiserum to charcoal-treated bFF (protein content $80 \mathrm{mg}$ $\mathrm{ml}^{-1}$ ) was produced in 4 adult ovariectomized ewes, as described by Alvarez et $a l .^{2}$. This antiserum was able to block the suppressive effect of bFF on plasma FSH concentrations in ovariectomized prepubertal heifers.

\section{Animals and experimental design}

Ten cyclic multiparous non-lactating Mantiqueira cows (a Brazilian Bos taurus dairy breed) were used in this study. Cows with a body condition score of 2.5 to 3 (scale of 1 to 5$)^{10}$ were maintained on Brachiaria decumbens pastures at the beginning of the experiment. Eight to twelve days after a prostaglandin-induced estrus, the cows were randomly assigned to two groups of five animals each. One group was injected i.v. with $100 \mathrm{ml}$ anti-bFF while the other group (control) received $100 \mathrm{ml}$ nonimmune serum from ovariectomized ewes. Six hours later, hyperstimulation was started in all cows with 250 IU FSH (17.5 NIH-FSH-S1 units) plus $250 \mathrm{IU}$ LH (0.23 NIH-LH-S1 units; Pluset, Lab. Serono, Rome, Italy) administered i.m. twice daily in decreasing doses (100, 75, 50 and $25 \mathrm{IU}$ at 08:00 and 20:00 h) over $4 \mathrm{~d}$. A luteolytic dose (1 mg) of the prostaglandin analogue, cloprostenol (Veteglan, Lab. Serono, Rome, Italy) was administered at the time of the fifth FSH-LH injection. Cows were observed for estrus and inseminated twice, 48 and 60 hours after the administration of cloprostenol, using frozen-thawed semen from the same ejaculate. Nonsurgical embryo collection was performed at Day 7 after insemination and embryos were evaluated as transferable or nontransferable based on morphological criteria using the International Embryo Transfer Society method ${ }^{24}$. After embryo collection, cows were slaughtered, the reproductive organs recovered and the number of the corpora lutea $(\mathrm{CL}$; a measure of the number of ovulations) and unovulated follicles greater than 10 $\mathrm{mm}$ in diameter recorded. Blood samples $(10 \mathrm{ml})$ of jugular cannulated animals were collected into heparinized tubes at 2-hours intervals beginning 2 hours before the ovine serum or antiserum administration (using the cannulae as way of application). Twentyfour hours later, the interval was increased to 8 hours until 36 hours after the cloprostenol injection. Thereafter, the interval was reduced to every 2 hours for the next 24 hours and then continued every 12 hours until the day of embryo recovery. Blood samples were centrifuged within $30 \mathrm{~min}$ after collection and the plasma recovered and stored at $-18^{\circ} \mathrm{C}$ until assayed.

\section{Hormone Radioimmunoassay}

Plasma gonadotrophin concentrations were measured using the heterologous radioimmunoassays described by Bolt and Rollins ${ }^{6}$ for FSH and Niswender et al. ${ }^{21}$ for LH as modified by Alvarez ${ }^{1}$. Highly purified bovine FSH (USDA-bFSH-1-2) was used as a standard as well as for iodination and the FSH antiserum was antioFSH (rabbit) NIDDK-oFSH-I-1 (AFP-C5288113). The intra-and interassay coefficients of variation $(\mathrm{CV})$ averaged respectively 4.2 and $12.2 \%$. Sensitivity of the bFSH was $1.4 \mathrm{ng} \mathrm{ml}^{-1}$. Plasma LH concentrations were measured using USDA -bLH-I-1 as standard as well as for iodination and the LH antiserum was NIADDK-oLH1 (AFP-192279). Intra-and interassay CV averaged respectively 4.7 and $8.6 \%$. Sensitivity of the bLH was $0.1 \mathrm{ng} \mathrm{ml}^{-1}$. The criterion used to define the onset of the preovulatory surge of LH was two SD exceeding the mean of 5 to 10 values preceding the onset of the surge as determined visually ${ }^{28}$.

Progesterone concentrations were determined by extraction radioimmunoassay (using twice-distilled ether anhydrous) as previously described by Belanger et al. ${ }^{4}$ and validated by Alvarez ${ }^{1}$. The antisera for progesterone were courtesy of F. Labrie (CHUL, Quebec, Canada). Progesterone concentrations were assayed in a single assay. The sensitivity of the assay was $0.4 \mathrm{ng} \mathrm{ml}^{-1}$ and the intra-assay $\mathrm{CV}$ was $3.3 \%$.

\section{Statistical analysis}

Plasma hormone concentrations were analyzed by ANOVA for repeated measures. A Student's $t$-test was used to determine differences between treatments for the number of CL (ovulation rate), anovulatory follicles, and total and transferable embryos. Differences between groups in the number of animals with poor response (defined as <3 CL) were analyzed by Chi-square test. Relationships between hormone concentrations (at the time of the beginning of treatments, surge of gonadotrophins and at the time of embryo collection) and ovulation rate, total and transferable embryos were determined by regression analysis.

\section{RESULTS}

\section{Ovarian response}

The data comparing the ovarian response of bFFimmunized and control cows are presented in Tab. 1.

All cows from the immunized group and 3 out of 5 cows in the control group had a good response to superovulation ( $p>0.05)$. There was no effect of anti-bFF treatment on the ovulation rate and number of anovulatory follicles present at the time of the embryo collection. The number of recovered embryos was not different between the two treatment groups, although cows immunized against bFF had a greater number of transferable embryos when compared with control animals $(\mathrm{p}<0.05)$.

\section{Endocrine profiles}

A cow from the control group which did not have a preovulatory LH surge was excluded from the analysis of endocrine profiles after the superovulatory treatment.

There were no differences in plasma gonadotrophin concentrations between immunized and control animals. The basal levels of plasma FSH ranged from 4 to $6 \mathrm{ng} \mathrm{ml}^{-1}$. Concentrations of FSH were not altered by the immunization or exogenous FSH treatment (Fig. 1). 
Table 1

Effect of passive immunization against bFF on the ovarian response of superovulated cows. Pindamonhangaba - SP, 1995.

\begin{tabular}{lccc}
\hline \multirow{2}{*}{ Variable } & \multicolumn{2}{c}{ Treatment group } & \multirow{2}{*}{$\mathrm{p}$} \\
\cline { 2 - 3 } & Immunized & Control & \\
\hline Cows & 5 & 5 & \\
Poor responders* & 0 & 2 & $\mathrm{NS}$ \\
Ovulations & $14.4 \pm 3.4$ & $9.0 \pm 3.5$ & $\mathrm{NS}$ \\
Anovulatory follicles & $2.4 \pm 1.1$ & $4.6 \pm 1.2$ & $\mathrm{NS}$ \\
Total embryos & $7.8 \pm 3.0$ & $5.8 \pm 2.7$ & $\mathrm{NS}$ \\
Transferable embryos & $3.4 \pm 1.0$ & $0.8 \pm 0.4$ & $<0.05$ \\
\hline
\end{tabular}

* Cows with <3 CL.

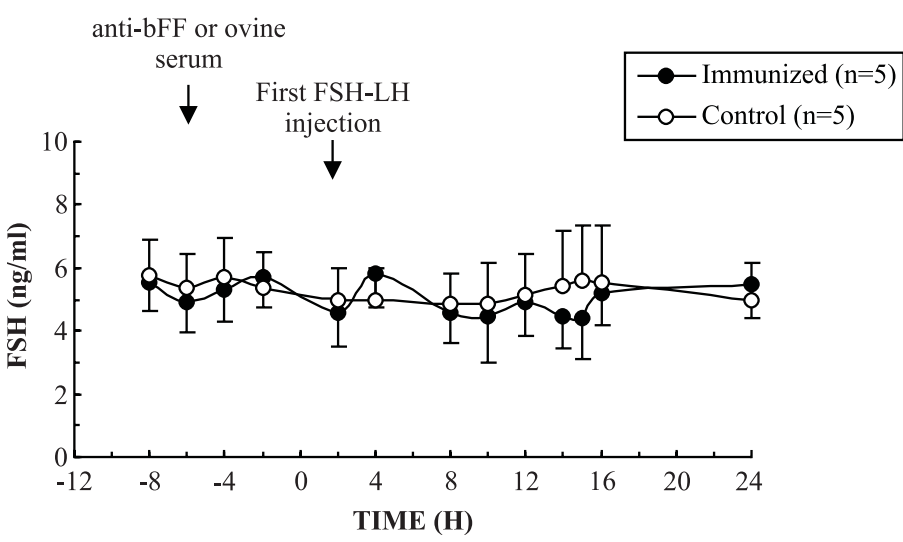

Figure 1

Mean $( \pm$ SEM) plasma concentrations of follicle-stimulating hormone (FSH) around the time of passive immunization against bovine follicular fluid and superovulation treatment.

The basal concentrations of plasma LH were below $2.5 \mathrm{ng}$ $\mathrm{ml}^{-1}$ for both control and immunized cows. A preovulatory surge of FSH (approximately a twofold increase) and LH was observed after cloprostenol-induced luteolysis in both control and immunized groups (Fig. 2).

The amplitudes of the preovulatory FSH and LH surges did not differ between treatments. The mean time interval between cloprostenol injection and the occurrence of the preovulatory $\mathrm{LH}$ surge was not significantly different between immunized (45.2 \pm 0.5 hours $)$ and control (42.0 \pm 0.8 hours) cows. Plasma gonadotrophin concentrations were not correlated with ovulation rate or recovered embryos.

Profiles of plasma progesterone concentrations in both immunized and control cows are shown in Fig. 3.

There were no significant differences in circulating levels of progesterone between the control and immunized groups. In both groups, cloprostenol treatment induced luteolysis as indicated by a fall in plasma progesterone concentrations, which were less than $1 \mathrm{ng} \mathrm{ml}^{-1}$ during the LH surge. Plasma progesterone concentrations at the time of embryo collection was positively correlated with ovulation rate $(\mathrm{r}=0.88, \mathrm{p}<0.01)$ but not with recovered total $(r=0.47, p>0.05)$ or transferable $(r=0.66, p>0.05)$ embryos.

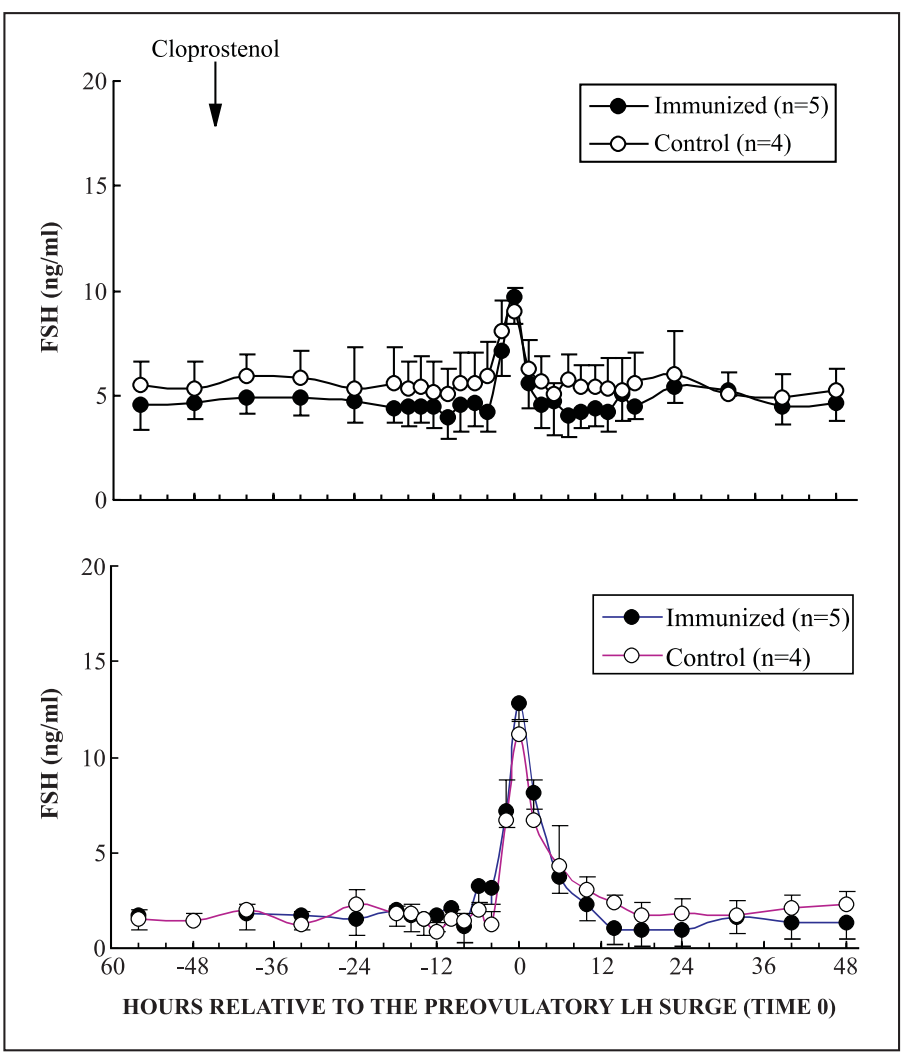

Figure 2

Mean $( \pm$ SEM) plasma concentrations of follicle-stimulating hormone (FSH) and luteinizing hormone (LH) in bFF immunized and control cows during the LH surge $(0 \mathrm{~h})$.

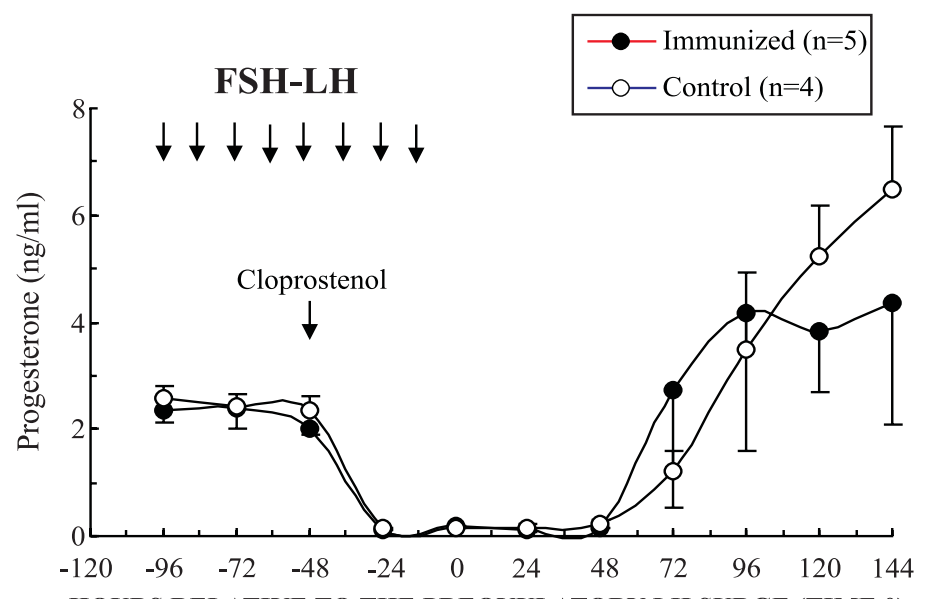

HOURS RELATIVE TO THE PREOVULATORY LH SURGE (TIME 0)

Figure 3

Mean $( \pm$ SEM) plasma progesterone concentrations in superovulated cows treated with nonimmune (control group) or immune anti bovine follicular fluid (immunized group) serum.

\section{DISCUSSION}

The present study showed that the administration of antiserum against bFF before gonadotrophin treatment does not reduce the variability in superovulation response in cattle. However, since all anti-bFF immunized cows and 3 out of 5 nonimmunized control cows had a good response to superovulation 
( $\geq 3 \mathrm{CL}$ ), the low superovulatory response of the control group could be due to the superovulatory dose used in the present study which corresponds to half the dose recommended by the manufacturer for inducing superovulation in cows. Then, it may be possible that bFF antiserum positively increased sensitivity to exogenous gonadotrophins.

A marked increase in the number of follicles in the middle of the estrous cycle of cows passively immunized against inhibin, alone or combined with estradiol, was attributed to the rise in plasma concentrations of $\mathrm{FSH}^{14}$. However, recent studies carried out in non-superovulated cattle showed that passive immunization against inhibin ${ }^{25}$ and to a lesser extent $\mathrm{bFF}^{1}$, increased the ovulation rate. However, in the former study the increase in ovulation rate was associated with high plasma concentrations of FSH while in the latter such association was not observed.

Scanlon et al. $^{23}$ showed that the ovulation rate in immunized animals is related, in some circumstances, to antibody titers against inhibin but changes in hormone concentration and dynamics of follicular growth were unrelated to titer of inhibin antibodies. Inhibin antibodies titers were not estimated in the anti-bFF used in the present study. In addition to inhibin, bFF contains many other proteinaceous components, some of which have been implicated as having an intragonadal role in follicular development ${ }^{26}$. In ewes ${ }^{9}$ and heifers ${ }^{16}$, the administration of inhibin-reduced (>90\%) bovine follicular fluid suppressed follicular development and consequently delayed the return to estrus following induced luteolysis. However, the altered follicular development was not attributed to reduced circulating concentrations of FSH.

Plasma gonadotrophin concentrations were similar for both groups, and were generally in accordance with those reported for superovulated cattle ${ }^{20,22,28}$. Because the radioimmunoassay of gonadotrophins used in the present study does cross-react slightly with exogenous FSH (from porcine pituitary source), it is believed that the plasma FSH and LH concentrations, during the period of superovulatory treatment represent only endogenous hormones. Luteolysis was completed 24-30 hours after cloprostenol administration. All cows, except one from the control group, had a single LH surge. This cow failed to superovulate but probably did ovulate later (outside from the frequent sampling period) since a single functional CL was observed at the time of embryo collection.

In contrast to Callesen et al. ${ }^{8}$ who reported a correlation between embryo quality and cows that had a high LH peak, neither LH nor FSH peak concentrations were correlated with embryo production or quality. Only progesterone measured on the day of embryo recovery was associated with the number of CL but not with embryo production or quality. This result may be considered normal since the embryo recovery rate (number of embryos/number of CL) was approximately $50 \%$.

In conclusion, results from the present study suggest that passive immunization of cows against bFF before superovulation did not reduce the variability of ovarian response. Data also suggest that passive immunization against bFF may improve superovulatory response. However, such an effect needs to be confirmed with a greater number of animals.

\section{ACKNOWLEDGEMENTS}

The authors wish to thank Dr. D.J. Bolt (USDA, Beltsville, MD), Dr. S. Raiti (NIDDK, Baltimore) and Dr. F. Labrie (CHUL, Quebec) for providing the reagents used for the hormone assay and Dr. J. P. Kastelic (The Lethbridge Research Center - AAFC) for their critical review and suggestions.

\section{RESUMO}

Dez vacas multíparas, secas, foram distribuídas aleatoriamente em dois grupos de cinco animais cada. Nos dias 8 a 12 do diestro, o primeiro grupo recebeu $100 \mathrm{ml}$ de anti-soro contra líquido folicular livre de esteróides (anti-LFb) produzido em ovelhas ovariectomizadas. O segundo grupo (controle) recebeu $100 \mathrm{ml}$ de soro de ovelhas não-imunizadas. Seis horas após a aplicação, os dois grupos foram superovulados com FSH (18 NIH-FSH-S1 unidades) e LH (0,29 NIH-LH-S1 unidades) administrados em quantidades decrescentes durante quatro dias. Na manhã do terceiro dia, foi administrada uma dose luteolítica de cloprostenol. Duas inseminações foram realizadas 48 e 60 horas após. Os embriões foram recuperados pelo método cervical 7 dias após a primeira inseminação. Amostras de sangue foram coletadas durante todo o período experimental para determinar, por radioimunoensaio, as concentrações plasmáticas de FSH, LH e progesterona. Todas as vacas do grupo imunizado e 3 do grupo controle apresentaram mais de 2 CL. Não existiu diferença significativa ( $>>0,05)$ na taxa de ovulação entre os grupos imunizado e controle $(14,4$ e 9,9, respectivamente). O número de embriões recuperado não foi significativamente diferente $(\mathrm{p}>0,05)$ entre os grupos, embora o grupo imunizado tenha apresentado maior número de embriões transferíveis $(3,4 \pm 1,0$ versus $0,8 \pm 0,4, p<0,05)$. As concentrações de gonadotrofinas plasmáticas não foram correlacionadas com a taxa de ovulação ou com o número de embriões recuperados. As concentrações de progesterona plasmática foram positivamente correlacionadas $(\mathrm{r}=0,88, \mathrm{p}<0,01)$ com a taxa de ovulação. Os resultados sugerem que o anti-LFb, aplicado antes da superovulação, não reduz a variabilidade da resposta ovariana.

UNITERMOS: Superovulação; Fluido folicular; Imunização passiva; Embriões; Bovinos. 


\section{REFERENCES}

1- ALVAREZ, R.H. Efeito da imunização passiva contra o líquido folicular bovino na taxa de ovulação e na produção de embriões de vacas superovuladas e não superovuladas. Jaboticabal, 1995. 192p. Tese (Doutorado). Faculdade de Ciências Agrárias e Veterinárias, Universidade Estadual Paulista.

2- ALVAREZ, R.H.; ARCARO, J.R.P.; RIBELA, M.T.C.P.; PERONE, C.N. Effect of charcoal-treated bovine follicular fluid on secretion of FSH in ovariectomized and intact prepubertal heifers. Brazilian Journal of Veterinary Research and Animal Science, v.35, n.5, 1996.

3- ARMSTRONG, D.T. Recent advances in superovulation of cattle. Theriogenology, v.39, n.1, p.7-24, 1993.

4- BELANGER, A.; CARON, S.; PICARD, V. Simultaneous radioimmunoassay of progestins, androgens and oestrogens in rat testis. Journal of Steroid Biochemistry, v.13, p.185-90, 1980.

5- BOLAND, M.P.; GOULDING, D.; ROCHE, J.F. Alternative gonadotrophins for superovulation in cattle. Theriogenology, v.35, n.1, p.5-17, 1991.

6- BOLT, D.J.; ROLLINS, R. Development and application of a radiommunoassay for bovine follicle-stimulating hormone. Journal of Animal Science, v.56, n.1, p.146-54, 1983.

7- BUNGARTZ, L.; NIEMANN, H. Assessment of the presence of a dominant follicle and selection of dairy cows suitable for superovulation by a single ultrasound examination. Journal of Reproduction and Fertility, v.101, n.3, p.583-91, 1994.

8-CALLESEN, H.; GREVE, T.; HYTTEL, P. Preovulatory endocrinology and oocyte maturation in superovulated cattle. Theriogenology, v.25, n.1, p.71-83, 1986.

9- CAMPBELL, B.K.; PICTON, H.M.; MANN, G.E.; MCNEILLY, A.S.; BAIRD, D.T. Effect of steroid-and inhibin -free ovine follicular fluid on ovarian follicles and ovarian hormone secretion. Journal of Reproduction and Fertility, v.93, n.1, p.81-96, 1991 .

10- EDMONSON, A.J.; LEAN, I.J.; WEAVER, L.D.; FARVER, T.; WEBSTER, G. A body condition scoring chart for holstein dairy cows. Journal of Dairy Science, v.72, n.1, p.68-78, 1989.

11- GONG, J.G.; BRAMLEY, T.A.; WILMUT, I.; WEBB, R. Effect of recombinant bovine somatotropin on the superovulatory response to pregnant mare serum gonadotropin in heifers. Biology of Reproduction, v.48, n.5, p.1141-9, 1993.

12- GREVE, T. Embryo transplantation in dairy cattle: an attempt to analyze factors that may affect embryo number and quality. In: WORLD CONFERENCE ON EMBRYO TRANSFER AND IN VITRO FERTILIZATION. 2., Annecy, 1982. Proceedings. Annecy : International Embryo Transfer Society, 1982. p.251-76.

13-GREVE, T.; CALLESEN, H.; HYTTEL, P.; HOIER, R.; ASSEY, R. The effects of exogenous gonadotropins on oocyte and embryo quality in cattle. Theriogenology, v.43, n.1, p.41-50, 1995.

14- KANEKO, H.; NAKANISHI, Y.; AKAGI, S.; ARAI, K.; TAYA, K.; WATANABE, G.; SASAMOTO, S.; HASEGAWA, Y. Immunoneutralization of inhibin an estradiol during the follicular phase of the estrous cycle in cows. Biology of Reproduction, v.53, n.4, p.931-9, 1995.

15- KO, J.C.H.; KASTELIC, J.P.; DEL CAMPO, M.R.; GINTHER, O.J. Effect of dominant follicle on ovarian follicular dynamics during the oestrous cycle in heifers. Journal of Reproduction and Fertility, v.91, n.2, p.511-9, 1991.

16- LAW, A.S.; BAXTER, G.; LOGUE, D.N.; O'SHEA, T.; WEBB, R. Evidence for the action of bovine follicular fluid factor(s) other than inhibin in suppressing follicular development and delaying estrous in heifers. Journal of Reproduction and Fertility, v.96, n.2, p.603-16, 1992.

17- MONNIAUX, D.; CHUPIN, D.; SAUMANDE, J. Superovulatory responses of cattle. Theriogenology, v.19, n.1, p.55-81, 1983.

18-MOOR, R.M.; KRUIP, T.A.M.; GREEN, D. Intraovarian control of folliculogenesis: Limits to superovulation?. Theriogenology, v.21, n.1, p.103-16, 1984.

19- MURPHY, B.D.; MAPLETOFT, R.J.; HUMPHREY, W.D. Variability in gonadotrophin preparations as a factor in the superovulatory response. Theriogenology, v.21, n.1, p.117-25, 1984.

20-NIBART, M.; SLIMANE, N.; HERRERA, R.; JEANGUYOT, N.; MECHEKOUR, F.; HUMBLOT, P.; THIBIER, M. Variations des concentrations plasmatiques des hormones gonadotropes ( $\mathrm{FSH}, \mathrm{LH}$ ) et steroides (oestradiol-17b, progesterone) après differents traitements de superovulation chez la vache. Elevage et Insemination, n.226 p.11-30, 1988.

21- NISWENDER, G.D.; REICHERT Jr., L.E.; MIDGLEY Jr., A.R.; NALBANDOV, A.V. Radiommunoassay for bovine and ovine luteinizing hormone. Endocrinology, v.84, n.5, p.1166-73, 1969.

22- SAUMANDE, J. Concentrations of luteinizing hormone, oestradiol-17b and progesterone in the plasma of heifers treated to induce superovulation. Journal of Endocrinology, v.84, n.3, p.425-47, 1980.

23- SCANLON, A.R.; SUNDERLAND, S.J.; MARTIN, T.L.; GOULDING, D.; O'CALLAGHAN, D.; WILLIAMS, D.H.; HEADON, D.R.; BOLAND, M.P.; IRELAND, J.J.; ROCHE, F. Active immunization of heifers against a synthetic fragment of bovine inhibin. Journal of Reproduction and Fertility, v.97, n.1, p.213-22, 1993.

24- STRIGFELLOW, D.A.; SEIDEL, S.M. Manual of the international embryo transfer society: a procedural guide and general information for the use of embryo transfer technology, emphasizing sanitary precautions. 2.ed. Champaign : International Embryo Transfer Society, 1990. p.14-6.

25- TAKEDOMI, T.; KANEKO, H.; AOYAGI, Y.; NAKANISHI, Y.; TAYA, K. Effects of passive immunization against bovine inhibin on ovulation rate and circulating FSH level in Holstein heifers. Theriogenology, v.43, n.1, p.333, 1995. (Abstract)

26- TONETTA, S.A.; DIZEREGA, G.S. Intragonadal regulation of follicular maturation. Endocrine Reviews. v.10, p.205-29, 1989.

27- TOUATI, K.; BECKERS, J.F.; ECTORS, F. Hormonal control of folliculogenesis in the bovine: better superovulatory responses after pure FSH administration preceding the classical treatment. Theriogenology, v.35, n.1, p.285, 1991 (Abstract)

28- YADAV, M.C.; WALTON, J.S.; LESLIE, K.E. Timing of the onset and duration of ovulation in superovulated beef heifers. Theriogenology, v.26, n.4, p.509-21, 1986 